\title{
Type IV collagen alpha chains of the basement membrane in the rat bronchioalveolar transitional segment
}

\author{
Noriko Hinenoya ${ }^{1}$, Ichiro Naito ${ }^{1,3}$, Ryusuke Momota ${ }^{1}$, Yoshikazu Sado ${ }^{4}$, Kanae \\ Kumagishi ${ }^{1}$, Yoshifumi Ninomiya², and Aiji Ohtsuka ${ }^{1}$
}

Departments of ${ }^{1}$ Human Morphology, and ${ }^{2}$ Molecular Biology and Biochemistry, Okayama University Graduate School of Medicine, Dentistry and Pharmaceutical Sciences, Okayama; ${ }^{3}$ Department of Nursing, Niimi College, Niimi; and

${ }^{4}$ Shigei Medical Research Institute, Okayama, Japan

Summary. In the present study, we have analyzed the $\alpha($ IV) chain distribution in the subepithelial basement membrane (BM) of the rat pulmonary airway from the bronchi to alveoli. We have furthermore analyzed the $\alpha(I V)$ chain distribution in the subepithelial BM of the bronchioalveolar duct junction (BADJ) using $\alpha(\mathrm{IV})$ chain specific monoclonal antibodies. Our results show that the $B M$ of the bronchial and bronchiolar epithelium contains $\left[\alpha 1(\text { IV) }]_{2} \alpha 2(\right.$ IV) and [ $\alpha 5$ (IV) $]_{2} \alpha 6$ (IV) molecules and confirmed that the alveolar BM consists of $[\alpha 1(\mathrm{IV})]_{2} \alpha 2(\mathrm{IV})$ and $\alpha 3(\mathrm{IV})$ $\alpha 4$ (IV) $\alpha 5$ (IV) molecules. There are also small regions in BADJ consisting of only [ $\alpha 1$ (IV) $]_{2} \alpha 2$ (IV) molecules without $\alpha 3$ (IV) $\alpha 4$ (IV) $\alpha 5$ (IV) and [ $\alpha 5$ (IV)] $\alpha_{2} \alpha 6($ IV) molecules. Moreover, the bronchioalveolar stem cells (BASCs)-primordial cells for bronchiolar Clara cells and alveolar type II (AT2) cells - lie adjacent to such small regions. These findings suggest that $[\alpha 1(\mathrm{IV})]_{2}$ $\alpha 2$ (IV) may be important for the BASCs to self-renew or to self-maintain themselves and that microenvironments produced by $\alpha(I V)$ chains may be important for cell differentiation.

Received November 10, 2008

Address for correspondence: Dr. Aiji Ohtsuka, Department of Human Morphology, Okayama University Graduate School of Medicine, Dentistry and Pharmaceutical Sciences, 2-5-1 Shikata-cho, Okayama 700-8558, Japan

Phone: +81-86-235-7088, Fax: +81-86-235-7095

E-mail: aiji@md.okayama-u.ac.jp

\section{Introduction}

The epithelium of the pulmonary airway contains a wide variety of cellular populations, each of which resides in distinct anatomical locations. Basal, secretory, and ciliated cells line the conducting airways of the bronchial tree. The nonciliated columnar Clara cells constitute the majority of the terminal bronchiolar epithelium. The alveolar type I (AT1) and type II (AT2) cells constitute the alveolar epithelium (Kim et al., 2005). These epithelial cells are underlaid by a continuous thin sheet-like extracellular matrix, the basement membrane (BM), which separates the epithelial cells from the stroma. In addition, BM in the lung is found in the vascular endothelium and the smooth muscle cells. BM plays important roles in biological functions such as cell adhesion, differentiation, and migration (Brauer et al., 1989). Furthermore, in the renal glomerulus, BM contributes to the molecular sieve for the selective removal of small molecules from the blood (Hudson et al., 1993).

Type IV collagen, known to be a major structural component of BM, provides a scaffolding for the other BM constituents (Timpl, 1989). Type IV collagen has six genetically different $\alpha$ (IV) chains: $\alpha 1$ (IV)- $\alpha 6$ (IV) (Ninomiya et al., 1995; Sado et al., 1998). The $\alpha(\mathrm{IV})$ chains are structurally divided into three parts: the Cterminal non-collagenous domain (NC1), the N-terminal $7 \mathrm{~S}$ domain, and the central helical domain (Sado et al., 1998). These assemble to form three different trimeric molecules: [ $\alpha 1$ (IV)] $2 \alpha 2$ (IV), $\alpha 3$ (IV) $\alpha 4$ (IV) $\alpha 5$ (IV), and $[\alpha 5(\mathrm{IV})]_{2} \alpha 6$ (IV) (Gunwar et al., 1998; Sado et al., 1998; Boutaud et al., 2000; Borza et al., 2001). Distribution patterns of these molecules in various BMs 
have been analyzed using specific monoclonal antibodies against $\alpha(\mathrm{IV})$ chains. For example, $[\alpha 1 \text { (IV) }]_{2} \alpha 2(\mathrm{IV})$ molecule was detected in the BM of most tissues, and $\alpha 3$ (IV) $\alpha 4$ (IV) $\alpha 5$ (IV) molecule was confirmed in primordial and atretic ovarian follicles (Nakano et al., 2007), a part of the subepithelial BM of the alimentary canal (Sato et al., 2007), glomeruli (Ninomiya et al., 1995), alveoli (Saito et al., 2000) and the choroid plexus (Urabe et al., 2002). Also [ $\alpha 5(\mathrm{IV})]_{2} \alpha 6$ (IV) molecule was detected in the subepithelial BM of the alimentary canal (Sato et al., 2007), epidermal BM (Hasegawa et al., 2007) and all stages of the ovarian follicle (Nakano et al., 2007).

The $a(\mathrm{IV})$ chains of BM of the alveolar epithelium have been confirmed (Nakano et al., 2001). However, little is known about the distribution patterns of the $\alpha(\mathrm{IV})$ chains in the bronchioles and the bronchioalveolar duct junction (BADJ). In this study, we investigated the distribution of the $\alpha$ (IV) chains in bronchioles and alveoli, using immunofluorescence microscopy with specific monoclonal antibodies, to find the special regions consisting of only [ $\alpha 1$ (IV)] $2 \alpha 2$ (IV) molecule in the BADJ, where bronchioalveolar stem cells (BASCs) exist (Kim et al., 2005; Liu et al., 2008).

\section{Materials and Methods}

\section{Animals and tissues}

Male Wistar rats of 6 weeks of age were purchased from Japan SLC, Inc.. Under ether anesthesia, their anterior thoracic walls were removed. In order to inflate the lungs, O.C.T. compound (Sakura Finetek Japan Co., Ltd., Tokyo) diluted to $1 / 2$ with phosphate-buffered saline (PBS) was injected through the trachea. The lung tissues were then excised, embedded in O.C.T. compound, frozen in liquid nitrogen, and kept at $-80^{\circ} \mathrm{C}$. The frozen tissues were cut with a cryostat into $4-5 \mu \mathrm{m}$ sections, which were kept under $-30^{\circ} \mathrm{C}$.

\section{Antibodies}

The $\alpha(\mathrm{IV})$ chain-specific monoclonal antibodies H11, H22, H31, RH42, H52, b14, and H65 were used in this study (Table 1) (Ninomiya et al., 1995; Borza et al., 2002; Heidet et al., 2003). An affinity purified goat polyclonal antibody against Clara cell 10 protein (CC10 (T18)) (Santa Cruz Biotechnology, Inc., California, USA) and a rabbit polyclonal antibody against surfactant associated protein-C (SP-C (FL-197)) (Santa Cruz Biotechnology, Inc., California, USA) were used. BASCs have been reported to differentiate into Clara cells and AT2 cells and to express both $\mathrm{CC} 10$ and $\mathrm{SP}-\mathrm{C}$; thus, BASCs are termed double-positive cells (DPCs) (Kim et al., 2005). DAPI (4', 6-diamidino-2-phenylindole) (Molecular Probes, Oregon, USA) was used for nuclei staining.

\section{Common procedures in immunofluorescent staining}

Prior to immunostaining, frozen sections were dried and fixed with acetone for $10 \mathrm{~min}$. Then $6 \mathrm{M}$ urea in a glycine- $\mathrm{HCl}$ buffer ( $\mathrm{pH} 3.5)$ was applied to the sections for $15 \mathrm{~min}$ at room temperature in order to expose the reactive epitopes of the antibodies of $\mathrm{H} 11, \mathrm{H} 22, \mathrm{H} 31$, H52, and b14. All the washing was performed with phosphate-buffered saline (PBS) for 5 min three times. Just before the first antibody was applied, any non-specific reaction was blocked with $2.5 \%$ skimmed milk in PBS for $10 \mathrm{~min}$. After immunostaining as described below, the sections were mounted with Fluoromount (Diagnostic BioSystems).

\section{Immunofluorescent staining for $\alpha 1$ (IV) through $a 6$ (IV) chains}

The sections were incubated with the chain-specific antibodies for $60 \mathrm{~min}$ at room temperature and washed. An indirect immunofluorescent method using FITCconjugated goat anti-rat IgG (Santa Cruz Biotechnology, Inc., California, USA) was applied to detect the localization of primary antibodies.

\section{Double immunofluorescent staining for $a 4(I V)$ and $a 6(I V)$}

To distinguish the localizations of $\alpha 3$ (IV) $\alpha 4$ (IV) $\alpha 5$ (IV) and $[\alpha 5(\mathrm{IV})]_{2} \alpha 6$ (IV) molecules, we performed a double

Table 1. List of type IV collagen $\alpha$ chain-specific monoclonal antibodies (MAbs) used in this study.

\begin{tabular}{lll}
\hline MAbs & Epitopes & Usage \\
\hline H11 & $\alpha 1(\mathrm{IV})$ chain NC1 domain & indirect, direct \\
H22 & $\alpha 2(\mathrm{IV})$ chain NC1 domain & indirect \\
H31 & $\alpha 3(\mathrm{IV})$ chain NC1 domain & indirect \\
RH42 & $\alpha 4(\mathrm{IV})$ chain NC1 domain & direct \\
H52 & $\alpha 5(\mathrm{IV})$ chain NC1 domain & indirect \\
b14 & $\alpha 5(\mathrm{IV})$ chain NC1 domain & direct \\
H65 & $\alpha 6(\mathrm{IV})$ chain helical domain & indirect \\
\hline
\end{tabular}


staining of $a 4(\mathrm{IV})$ and $a 6(\mathrm{IV})$ chains. The sections were incubated with $\mathrm{H} 65$ for $60 \mathrm{~min}$ at room temperature and washed. In order to detect the localization of H65, Rhodamine-conjugated goat anti-rat IgG (Santa Cruz Biotechnology, Inc., California, USA) was applied for $60 \mathrm{~min}$ at room temperature. After washing, the sections were incubated with FITC-conjugated RH42 for $60 \mathrm{~min}$ at room temperature.

\section{Double immunofluorescent staining for $\alpha 1$ (IV) and a5(IV)}

The $\alpha 1(\mathrm{IV})$ chain comprises $[\alpha 1(\mathrm{IV})]_{2} \alpha 2(\mathrm{IV})$ molecule, while $\alpha 5$ (IV) chain comprises both $\alpha 3$ (IV) $\alpha 4$ (IV) $\alpha 5(\mathrm{IV})$ and $[\alpha 5(\mathrm{IV})]_{2} \alpha 6(\mathrm{IV})$ molecules. We performed a double staining of $\alpha 1$ (IV) and $\alpha 5$ (IV) chains to detect the area composed of only [ $\alpha 1$ (IV)] $2 \alpha 2$ (IV) molecules. The sections were incubated with FITCconjugated $\mathrm{H} 11$ for $60 \mathrm{~min}$ at room temperature and washed. They were then incubated with HiLyte555conjugasted b14 for $60 \mathrm{~min}$ at room temperature.

\section{Double immunofluorescent staining for CC10 and $S P-C$}

The sections were incubated with a mixture of antibodies against CC10 and SP-C for $60 \mathrm{~min}$ and washed. Then they were incubated with a mixture of FITC-conjugated donkey anti-goat IgG (Jackson ImmunoResearch Laboratories, Inc.) and Cy3-conjugated donkey anti-rabbit IgG (Jackson ImmunoResearch Laboratories, Inc.) for $60 \mathrm{~min}$ at room temperature.

\section{Fluorescence microscopy}

Immunostained sections were observed with a fluorescence microscope (IX71, Olympus, Tokyo) equipped with a digital camera (DP-70, Olympus).

\section{Results}

\section{Basement membranes of bronchi, bronchioles and alveoli}

Frozen sections of the rat inflated lung were morphologically well preserved without deformity and showed continuous linear images of the BM after the immunofluorescent staining. The subepithelial BM of the pulmonary airway contained all six $\alpha$ chains of the type IV collagen, the $\alpha 1$ (IV), $\alpha 2$ (IV), $\alpha 3$ (IV), $\alpha 4(\mathrm{IV})$, $\alpha 5$ (IV) and $\alpha 6$ (IV) chains (Table 2). The $\alpha 1$ (IV) and $a 2$ (IV) chains were detected continuously from the bronchi to alveoli. From the main bronchi to the terminal bronchioles, the BM beneath the epithelium showed positive immunofluorescence against the $\alpha 1$ (IV), $\alpha 2(\mathrm{IV}), \alpha 5(\mathrm{IV})$ and $\alpha 6$ (IV) chains, but no signal against the $a 3$ (IV) and $a 4$ (IV) chains. While the alveolar subepithelial BM showed positive immunofluorescence against the $\alpha 1$ (IV), $\alpha 2$ (IV), $\alpha 3$ (IV), $\alpha 4$ (IV) and $\alpha 5$ (IV) chains, there was no signal against the $a 6(\mathrm{IV})$ chain (Fig. 1). This staining pattern meant that the BM beneath the bronchial and bronchiolar epithelium contained [ $\alpha 1(\mathrm{IV})]_{2} \alpha 2(\mathrm{IV})$ and $[\alpha 5(\mathrm{IV})]_{2} \alpha 6$ (IV) molecules, and the BM beneath the alveolar epithelium contained [ $\alpha 1(\mathrm{IV})]_{2} \alpha 2$ (IV) and $\alpha 3$ (IV) $\alpha 4$ (IV) $\alpha 5$ (IV) molecules. In addition to that, the BM around smooth muscle fibers spirally arranged in the bronchiolar wall showed positive

Table 2. Immunohistochemical expression of type IV collagen $\alpha$ chains in the normal rat lung basement membrane (BM).

\begin{tabular}{lcccccc}
\hline & \multicolumn{5}{c}{ Type IV collagen $\alpha$ chains } \\
\cline { 2 - 6 } BM & $\alpha 1(\mathrm{IV})$ & $\alpha 2(\mathrm{IV})$ & $\alpha 3(\mathrm{IV})$ & $\alpha 4(\mathrm{IV})$ & $\alpha 5(\mathrm{IV})$ & $\alpha 6(\mathrm{IV})$ \\
\hline Alveolar epithelium & + & + & + & + & + & - \\
Bronchiolar epithelium & + & + & - & - & + & + \\
Blood vascular endothelium & + & + & - & - & - & - \\
Smooth muscle cells & + & + & - & - & + & + \\
\hline
\end{tabular}

+ : positive - : negative 


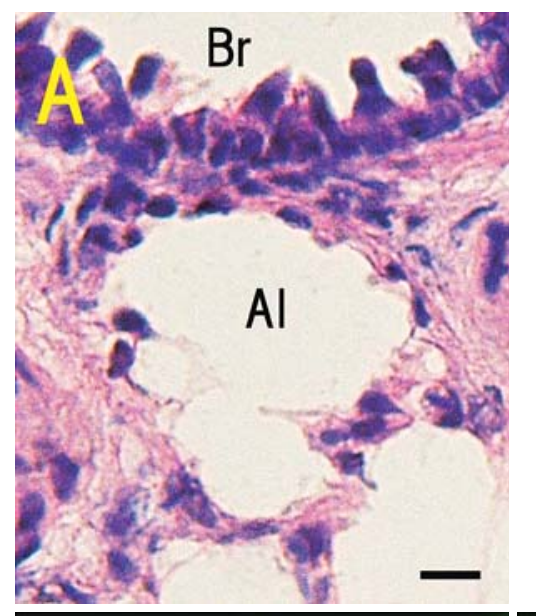

Fig. 1. Light micrographs of cryosections of rat terminal bronchioles $(\mathrm{Br})$ and alveoli (Al), stained with hematoxylin and eosin (A) and immunostained with monoclonal antibodies, specific for the $\alpha 1$ (IV) chain (B), $\alpha 2(\mathrm{IV})$ chain (C), $\alpha 3$ (IV) chain (D), $\alpha 4(\mathrm{IV})$ chain (E), $\alpha 5(\mathrm{IV})$ chain $(\mathbf{F})$, and $\alpha 6(\mathrm{IV})$ chain $(\mathbf{G})$. The subepithelial BM of terminal bronchiole and the $\mathrm{BM}$ around smooth muscle fibers react positively to anti- $\alpha 1$ (IV), anti- $\alpha 2$ (IV), anti- $\alpha 5$ (IV), and anti- $\alpha 6$ (IV) antibodies. The alveolar BM reacts positively to anti- $\alpha 1$ (IV) through anti- $\alpha 5$ (IV) antibodies. The subendothelial BM of blood vessels reacts positively to anti- $\alpha 1$ (IV) and anti- $\alpha 2$ (IV) antibodies. These results are summarized in Table 2. White arrows: subepithelial BM of terminal bronchioles, red arrows: alveolar BM, SM: BM around smooth muscle fibers, arrowheads: subendothelial BM of blood vessels. Bars: $10 \mu \mathrm{m}$
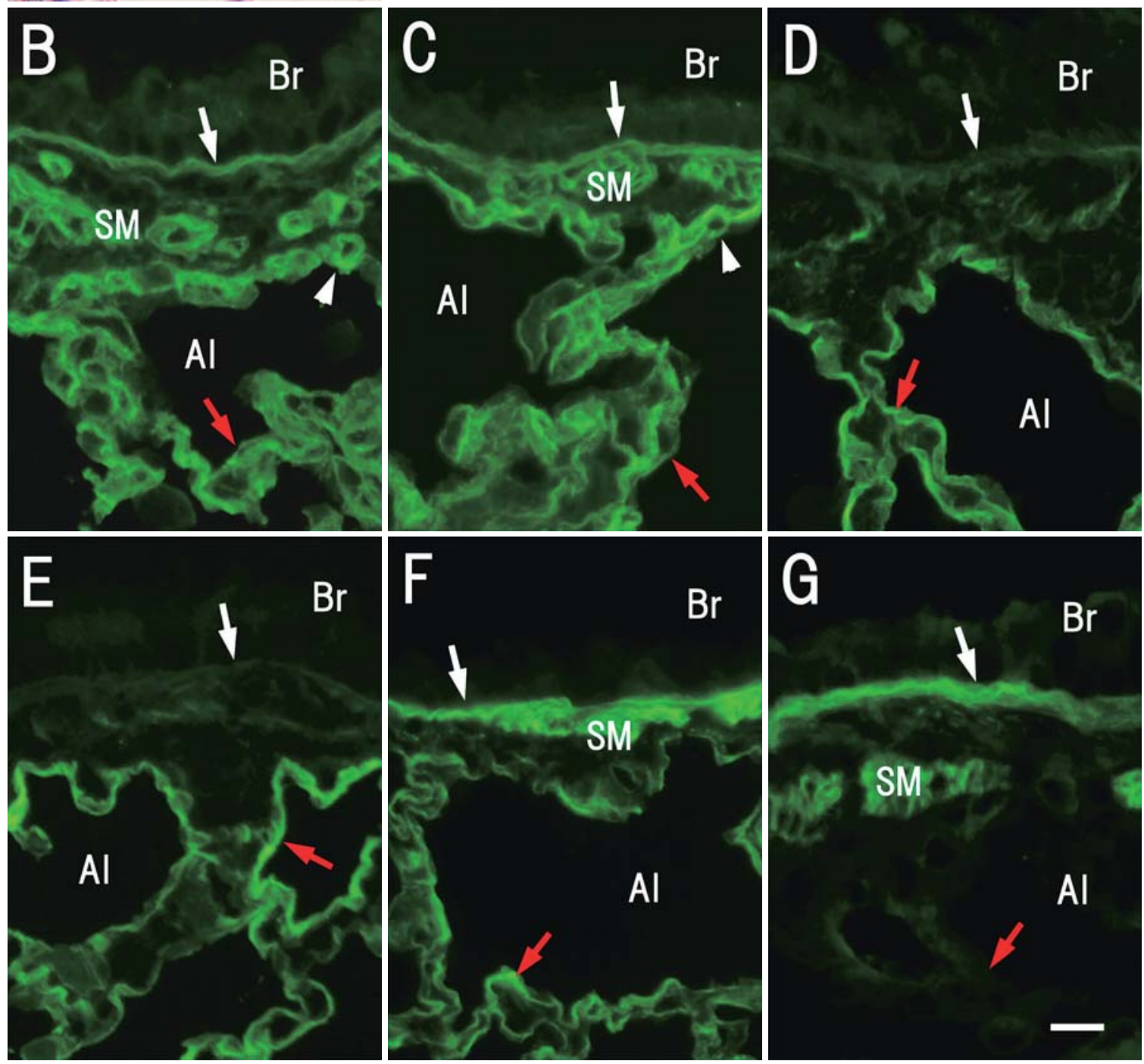


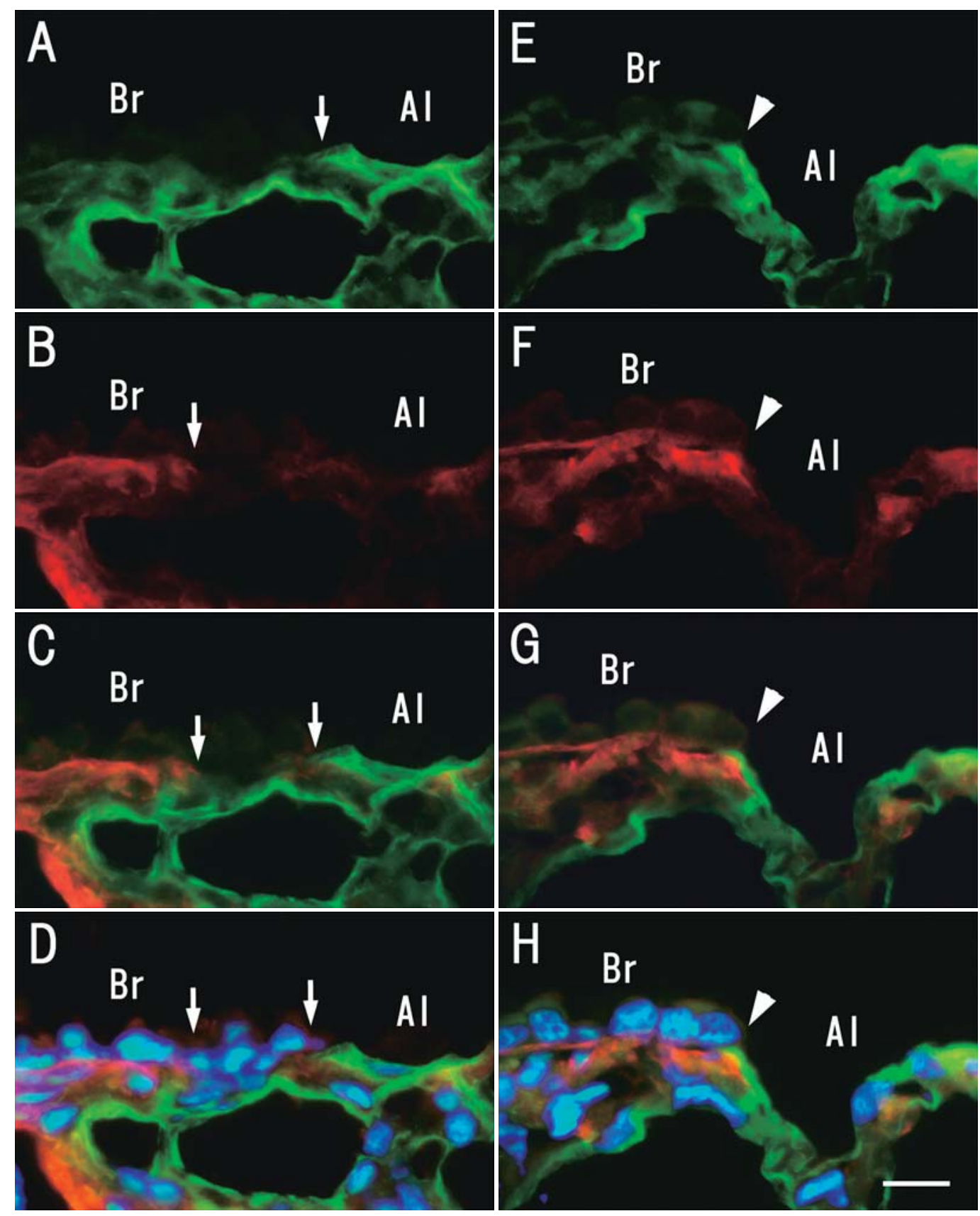

Fig. 2. Double immunofluorescent staining images for $\alpha 4(\mathrm{IV})$ and $\alpha 6(\mathrm{IV})$ chains in the BM of bronchioalveolar duct junction show two patterns. Arrows show the end of the BM, so that the areas between two arrows have neither $\alpha 3$ (IV) $\alpha 4$ (IV) $\alpha 5$ (IV) nor [ $\alpha 5(\mathrm{IV})]_{2} \alpha 6$ (IV) (A-D). Arrowheads indicate bronchioalveolar duct junctions. The BMs possessing the $a 4(\mathrm{IV})$ or $\alpha 6(\mathrm{IV})$ chain directly connect $(\mathbf{E}-\mathbf{H})$. $\mathbf{A}$ and E: the images of the $\alpha 4(\mathrm{IV})$ chain (green), B and F: the images of the $\alpha 6(\mathrm{IV})$ chain (red), $\mathbf{C}$ and $\mathbf{G}$ : merged images, $\mathbf{D}$ and $\mathbf{H}$ : merged images and DAPI (blue). Br: terminal bronchioles, Al: alveoli. Bar: 10 $\mu \mathrm{m}$ 


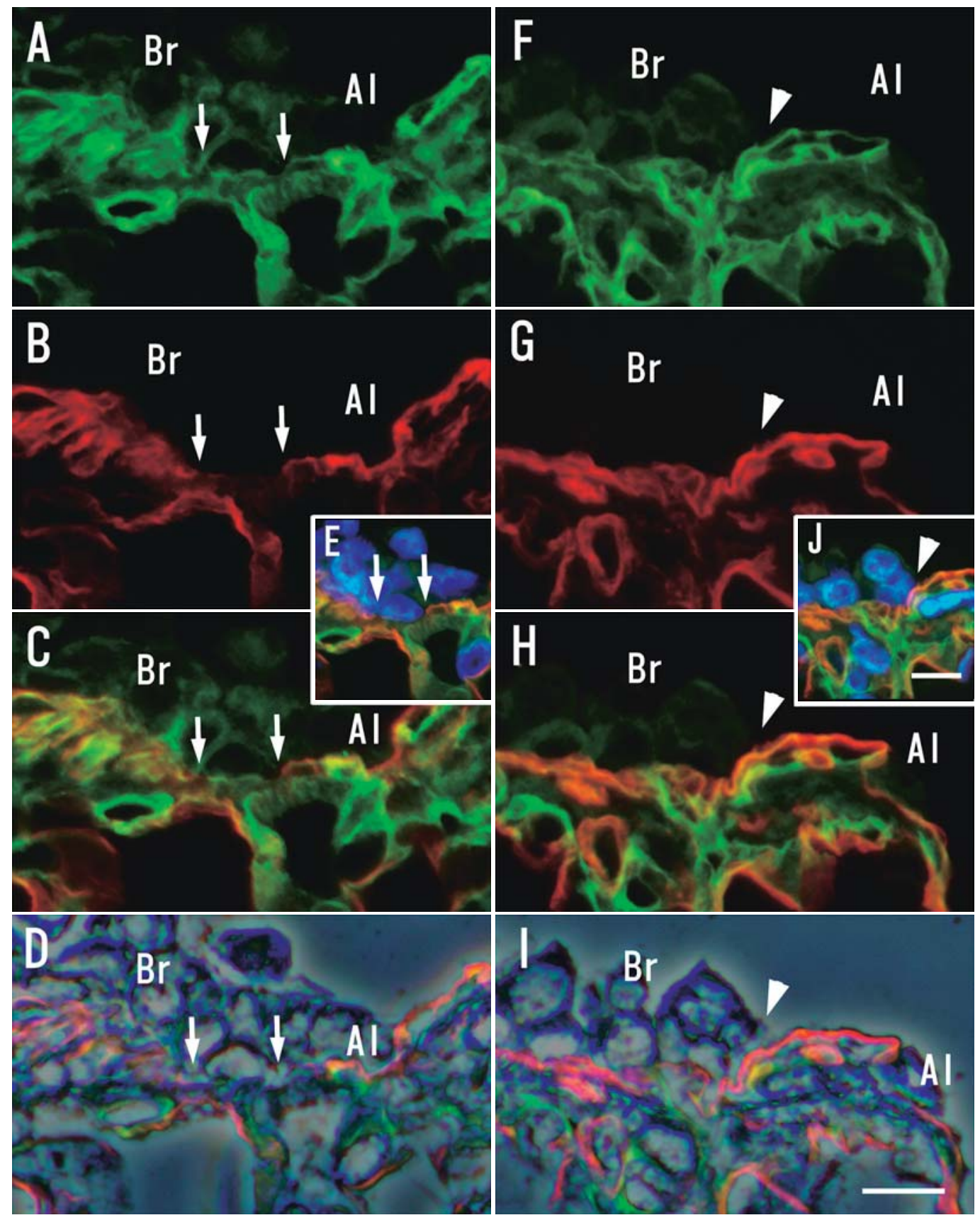

Fig. 3. Double immunofluorescent staining for $\alpha 1$ (IV) and $\alpha 5$ (IV) in the bronchioalveolar duct junction. Two patterns of immunostaining have been confirmed. The BM containing $\alpha 3$ (IV) $\alpha 4(\mathrm{IV}) \alpha 5(\mathrm{IV})$ molecule and that containing $[\alpha 5(\mathrm{IV})]_{2} \alpha 6(\mathrm{IV})$ molecule connect directly $(\mathbf{F}-\mathbf{J})$ or insert a short area of BM containing $[\alpha 1(\mathrm{IV})]_{2} \alpha 2(\mathrm{IV})$ molecule only $(\mathbf{A}-\mathbf{E})$. The width of the area is about a cell size (E). Arrows show the end of $\alpha 5(\mathrm{IV})$. Arrowheads show bronchioalveolar duct junctions. A and F: the images of $\alpha 1$ (IV) chain (green), $\mathbf{B}$ and $\mathbf{G}$ : the images of $\alpha 5$ (IV) chain (red), $\mathbf{C}$ and $\mathbf{H}$ : merged images, $\mathbf{D}$ and $\mathbf{I}$ : merged images and phase contrast images, $\mathbf{E}$ and $\mathbf{J}$ : merged images and DAPI (blue). Br: terminal bronchioles, Al: alveoli. Bars: $10 \mu \mathrm{m}$ 
Fig. 4. Double immunostaining images using antibodies against CC10 (A, green) and SP-C $(\mathbf{C}$, red) and double immunostaining images of the adjoining section using antibodies against $\alpha 1$ (IV) (E, green) and $a 5(\mathrm{IV})(\mathbf{G}$, red) in the bronchioalveolar duct junction of the rat. $\mathbf{B}$ and $\mathbf{F}$ : merged images, $\mathbf{D}$ and $\mathbf{H}$ : merged images and phase contrast images. Br: terminal bronchioles, Al: alveoli. A$\mathbf{D}$ and $\mathbf{E}-\mathbf{H}$ are serial sections. Double positive cells for $\mathrm{CC} 10$ and $\mathrm{SP}-\mathrm{C}$ are found at the end of columnar epithelial cells (A$\mathbf{D}$, arrows). In the same area of the adjoining section, the subepithelial BM has the $\alpha$ (IV) chain but not the $\alpha 5$ (IV) chain, indicating that the area has only [ $\alpha 1$ (IV)] $2 \alpha 2(\mathrm{IV})(\mathbf{E}-\mathbf{H})$. Bars: $10 \mu \mathrm{m}$
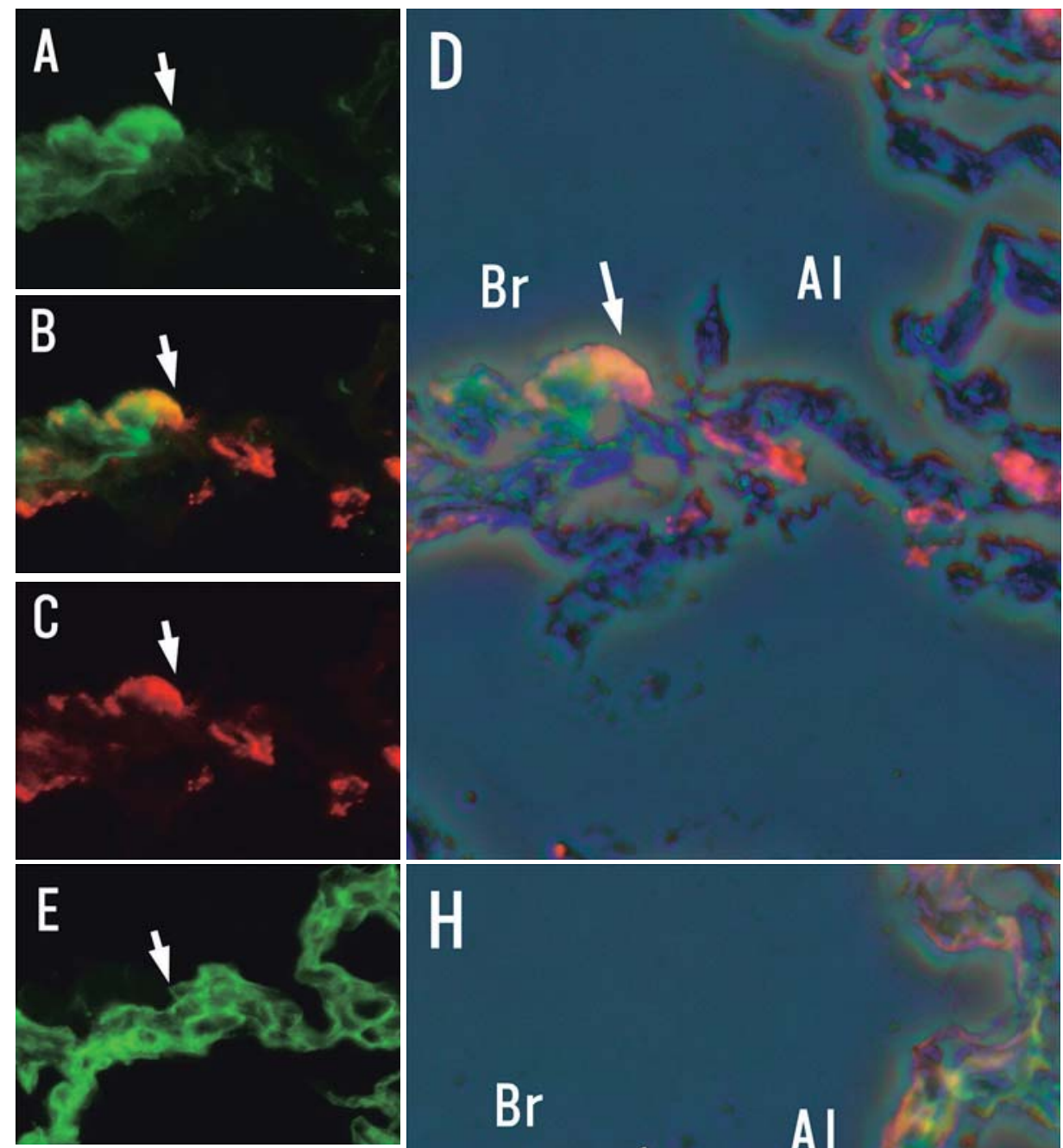

\section{$\mathrm{H}$}

$\mathrm{Br}$
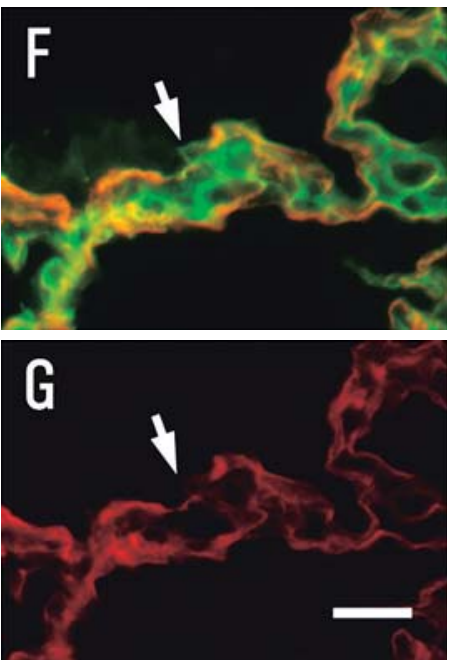
immunofluorescence against the $\alpha 1$ (IV), $\alpha 2$ (IV), $\alpha 5$ (IV) and $a 6$ (IV) chains. The subendothelial BM of blood vessels showed positive immunofluorescence against the $\alpha 1$ (IV) and $\alpha 2$ (IV) chains (Fig. 1).

\section{Alpha (IV) chains in the bronchioalveolar duct junction (BADJ)}

The double staining against the $\alpha 4$ (IV) and $\alpha 6$ (IV) chains showed two patterns of a transitional zone between the a4-positive alveolar type BM and $a 6$-positive bronchiolar type BM: a separate pattern with an a4negative/ $\alpha 6$-negative region (50\%), and a continuous pattern without an a4-negative/ $\alpha 6$-negative region (50\%) (Fig. 2). We carried out a double staining of the $\alpha 1$ and $\alpha 5$ chains to detect the $\alpha 1$-positive/ $\alpha 5$-negative areas that contained neither $\alpha 3$ (IV) $\alpha 4$ (IV) $\alpha 5$ (IV) nor [ $\alpha 5(\mathrm{IV})]_{2} \alpha 6$ (IV) molecules at continuous BM in the BADJ. In sections observed, 10 out of 14 junctions showed continuously positive labeling for both $a 1$ (IV) and $a 5$ (IV) chains $(71 \%)$, and 4 junctions contained a1-positive/ a 5-negative parts (29\%) (Fig. 3). We have noted cells adjacent to the small region-about a single cell dimension-where only [ $\alpha 1$ (IV) $]_{2} \alpha 2$ (IV) molecules existed. To determine whether these cells were bronchially or alveolarly derived, we used antibodies CC10 and SP-C to identify bronchial cells and alveolar type II cells, respectively. We observed 17 CC10-positive/ SP-C-positive cells. Fourteen $(82.4 \%)$ of them were positioned as the first or second cell from the bronchioalveolar epithelial transition end of bronchiolar epithelial cells, and the remaining $3(17.6 \%)$ were at the position of the third or fourth cell. To analyze the relationship between CC10-positive/SP-C-positive cells and the $\alpha(\mathrm{IV})$ chains, we performed a double staining of $\alpha 1$ (IV) and a5(IV) chains on the adjacent sections (Fig. 4). In 8 out of 9 pairs of junctions, CC10-positive/SP-C-positive cells were situated at the position of the first or the second cell from the bronchio-alveolar transition end point of the bronchiolar epithelial cells. Four CC10-positive/SPC-positive cells out of them were on the BM containing only the $a 1$ (IV) chain. The remaining 4 cells were on the BM containing both $\alpha 1$ (IV) and $\alpha 5$ (IV) chains. In 1 out of 9 pairs of junctions, the CC10-positive/SP-C-positive cell was located at the position of the fourth cell from the end of the bronchiolar epithelial cell and was on the BM containing both $\alpha 1(\mathrm{IV})$ and $\alpha 5$ (IV) chains.

\section{Discussion}

The present study has shown the distribution of type IV collagen $a$ chains in the subepithelial basement membrane (BM) of the rat lung by immunofluorescence microscopy using a chain-specific monoclonal antibodies. It has confirmed that the $[a 1 \text { (IV) }]_{2} a 2$ (IV) molecule continuously exists along the subepithelial BM from the bronchi to alveoli, and that the alveolar BM contains the $\alpha 3$ (IV) $\alpha 4$ (IV) $\alpha 5$ (IV) molecule (Nakano et al., 2001). In contrast, the bronchial and bronchiolar $\mathrm{BM}$ contain the $[a 5(\mathrm{IV})]_{2} a 6(\mathrm{IV})$ molecule instead of the $\alpha 3$ (IV) $\alpha 4$ (IV) $\alpha 5$ (IV) molecule. This bronchial type BM, containing both the $[\alpha 1(\mathrm{IV})]_{2} \alpha 2(\mathrm{IV})$ and $[\alpha 5(\mathrm{IV})]_{2} \alpha 6(\mathrm{IV})$ molecules, shows the same pattern of the collagen IV molecules seen in the epidermis (Hasegawa et al., 2007) as well as in the esophagus and other gastro-intestinal epithelia (Sato et al., 2007).

This bronchiolar type BM is common to the BM delineating epithelium facing both the outside and inside of the human body. The transitional segment from the bronchiolar type BM to the alveolar type BM was found at the point where columnar epithelial cells changed to flat ones. Because it is suggested that the BM is made by the adjoining cells (Ninomiya et al., 1995), we suppose that there is a close relationship between the epithelial cell type and collagen type IV molecules in the subepithelial BM.

In the transitional segment between the bronchiolar type BM and the alveolar type BM, a small part of the $\mathrm{BM}$ consisting of the $[\alpha 1 \text { (IV) }]_{2} \alpha 2$ (IV) molecule was confirmed to be aligned just beneath the CC10-positive/ SP-C-positive cells. This result suggests that CC10positive/SP-C-positive cells may produce only $\alpha 1$ (IV) and $\alpha 2(\mathrm{IV})$ chains but not $\alpha 3$ (IV), $\alpha 4$ (IV), $\alpha 5$ (IV) and $a 6$ (IV) chains. The CC10-positive/SP-C-positive cells are suggested to be bronchioalveolar stem cells (BASCs) (Kim et al., 2005), which self-renew themselves, and give rise to Clara cells, AT2 cells, or AT1 cells (either directly or via BASC-derived AT2 cells) (Giangreco et al., 2002; Kim et al., 2007). Thus, BASCs play an important role in both the maintenance and repair of bronchiolar and alveolar cells (Nolen-Walston et al., 2008). We presume that the BASCs, producing only the $[\alpha 1 \text { (IV) }]_{2} \alpha 2$ (IV) molecule in order to self-renew and self-maintain, obtain the ability to produce the $\alpha 3$ (IV) $\alpha 4$ (IV) $\alpha 5$ (IV) or [ $a 5(\mathrm{IV})]_{2} a 6(\mathrm{IV})$ molecule prior to the differentiation to bronchiolar or alveolar epithelial cells, respectively.

As shown in the present study, some BASCs were detected in the regions away from the BADJ, and the $\mathrm{BM}$ beneath such BASCs was positive to the $\alpha 5$ (IV) 
antibody. These cells might be an intermediate form or under differentiation and migrating from the BADJ to alveoli or bronchioles because they were positive against CC10 and SP-C and formed the $\alpha 5$ (IV) chain. Recently, type IV collagen has been shown to regulate bone morphogenetic protein (BMP) signaling by binding to BMP molecules (Wang et al., 2008). High local BMP signaling is observed in the germ line stem cell niche in Drosophila ovary. Thus, the variety of $\alpha$ (IV) chains may be important modulators for the BMP signaling that provides differentiation signals to the adjacent cells.

\section{Acknowledgements}

The authors would like to thank Mr. H. Mizoguchi, Mr. M. Narasaki, Mr. H. Osugi, and Mr. T. Komiyama (Department of Human Morphology) for their technical support.

\section{References}

Borza DB, Bondar O, Ninomiya Y, Sado Y, Naito I, Todd P, Hudson BG: The NC1 domain of collagen IV encodes a novel network composed of the alpha 1 , alpha 2, alpha 5, and alpha 6 chains in smooth muscle basement membranes. J Biol Chem 276: 28532-28540 (2001).

Borza DB, Bondar O, Todd P, Sundaramoorthy M, Sado Y, Ninomiya Y, Hudson BG: Quaternary organization of the Goodpasture autoantigen, the alpha 3(IV) collagen chain. Sequestration of two cryptic autoepitopes by intrapromoter interactions with the alpha4 and alpha5 NC1 domains. J Biol Chem 277: 40075-40083 (2002).

Boutaud A, Borza DB, Bondar O, Gunwar S, Netzer KO, Singh N, Ninomiya Y, Sado Y, Noelken ME, Hudson BG: Type IV collagen of the glomerular basement membrane. Evidence that the chain specificity of network assembly is encoded by the noncollagenous NC1 domains. J Biol Chem 275: 30716-30724 (2000).

Brauer PR, Keller JM: Ultrastructure of a model basement membrane lacking type IV collagen. Anat Rec 223: 376-383 (1989).

Giangreco A, Reynolds SD, Stripp BR: Terminal bronchioles harbor a unique airway stem cell population that localizes to the bronchoalveolar duct junction. Am J Pathol 161: 173-182 (2002).
Gunwar S, Ballester F, Noelken ME, Sado Y, Ninomiya Y, Hudson BG: Glomerular basement membrane. Identification of a novel disulfide-cross-linked network of alpha3, alpha4, and alpha5 chains of type IV collagen and its implications for the pathogenesis of Alport syndrome. J Biol Chem 273: $8767-8775$ (1998).

Hasegawa H, Naito I, Nakano K, Momota R, Nishida K, Taguchi T, Sado Y, Ninomiya Y, Ohtsuka A: The distributions of type IV collagen alpha chains in basement membranes of human epidermis and skin appendages. Arch Histol Cytol 70: 255-265 (2007).

Heidet L, Borza DB, Jouin M, Sich M, Mattei MG, Sado Y, Hudson BG, Hastie N, Antignac C, Gubler MC: A human-mouse chimera of the alpha3alpha4alpha5(IV) collagen protomer rescues the renal phenotype in Col4a3-/- Alport mice. Am J Pathol 163: 1633-1644 (2003).

Hudson BG, Reeders ST, Tryggvason K: Type IV collagen: structure, gene organization, and role in human diseases. Molecular basis of Goodpasture and Alport syndromes and diffuse leiomyomatosis. J Biol Chem 268: 26033-26036 (1993).

Kim CF, Jackson EL, Woolfenden AE, Lawrence S, Babar I, Vogel S, Crowley D, Bronson RT, Jacks T: Identification of bronchioalveolar stem cells in normal lung and lung cancer. Cell 121: 823-835 (2005).

Kim CF: Paving the road for lung stem cell biology: bronchioalveolar stem cells and other putative distal lung stem cells. Am J Physiol Lung Cell Mol Physiol 293: L1092-L1098 (2007).

Liu X, Engelhardt JF: The glandular stem/progenitor cell niche in airway development and repair. Proc Am Thorac Soc 5: 682-688 (2008).

Nakano K, Naito I, Momota R, Sado Y, Hasegawa H, Ninomiya Y, Ohtsuka A: The distribution of type IV collagen alpha chains in the mouse ovary and its correlation with follicular development. Arch Histol Cytol 70: 243-253 (2007).

Nakano KY, Iyama KI, Mori T, Yoshioka M, Hiraoka T, Sado Y, Ninomiya Y: Loss of alveolar basement membrane type IV collagen alpha3, alpha4, and alpha5 chains in bronchioloalveolar carcinoma of the lung. $J$ Pathol 194: 420-427 (2001).

Ninomiya Y, Kagawa M, Iyama K, Naito I, Kishiro Y, Seyer JM, Sugimoto M, Oohashi T, Sado Y: Differential expression of two basement membrane collagen genes, COL4A6 and COL4A5, demonstrated by immunofluorescence staining using peptide-specific monoclonal antibodies. J Cell Biol 130: 1219-1229 (1995). 
Nolen-Walston RD, Kim CF, Mazan MR, Ingenito EP, Gruntman AM, Tsai L, Boston R, Woolfenden AE, Jacks T, Hoffman AM: Cellular kinetics and modeling of bronchioalveolar stem cell response during lung regeneration. Am J Physiol Lung Cell Mol Physiol 294: L1158-1165 (2008).

Sado Y, Kagawa M, Naito I, Ueki Y, Seki T, Momota R, Oohashi T, Ninomiya Y: Organization and expression of basement membrane collagen IV genes and their roles in human disorders. J Biochem 123: 767-776 (1998).

Saito K, Naito I, Seki T, Oohashi T, Kimura E, Momota R, Kishiro Y, Sado Y, Yoshioka H, Ninomiya Y: Differential expression of mouse alpha5(IV) and alpha6(IV) collagen genes in epithelial basement membranes. J Biochem 128: 427-434 (2000).
Sato H, Naito I, Momota R, Naomoto Y, Yamatsuji T, Sado Y, Ninomiya Y, Ohtsuka A: The differential distribution of type IV collagen alpha chains in the subepithelial basement membrane of the human alimentary canal. Arch Histol Cytol 70: 313-323 (2007).

Timpl R: Structure and biological activity of basement membrane proteins. Eur J Biochem 180: 487-502 (1989).

Urabe N, Naito I, Saito K, Yonezawa T, Sado Y, Yoshioka H, Kusachi S, Tsuji T, Ohtsuka A, Taguchi T, Murakami T, Ninomiya Y: Basement membrane type IV collagen molecules in the choroid plexus, pia mater and capillaries in the mouse brain. Arch Histol Cytol 65: 133-143 (2002).

Wang X, Harris RE, Bayston LJ, Ashe HL: Type IV collagens regulate BMP signalling in Drosophila. Nature 455: $72-77$ (2008). 